\title{
Dampak Pandemi Covid-19 terhadap Perkembangan dan Prospek Perbankan Syariah
}

\author{
Annisa Nur Safitri ${ }^{1}$, Muhammad Iqbal Fasa ${ }^{\varpi_{2}}$, Suharto $^{3}$ \\ 1,2,3 Universitas Islam Negeri Raden Intan Lampung \\ DOI : https://doi.org/10.37531/ecotal.v2i2.66
}

\begin{abstract}
ABSTRAK
Pandemi Covid-19 telah menyebar ke berbagai negara, termasuk Indonesia. Jumlah kasus Covid19 yang semakin meningkat melemahkan perekonomian nasional maupun internasional. Berbagai sektor bisnis mengalami perlambatan akibat virus Covid-19. Dalam penelitian ini. diharapkan para pelaku ekonomi dan bisnis syariah menunjukkan empati dan solidaritas kepada para pemangku kepentingan. Pelaku bisnis syariah memanfaatkan dan mendukung program stimulus dari pemerintah. perbankan syariah dan lembaga keuangan lainnya harus mulai merevisi kembali target pertumbuhan, penerapan teknologi digital transaksi dalam satu solusi. Ekonomi dan bisnis syariah dapat berperan memulihakan guncangan ekonomi dengan mengedepankan pencapaian tujuan - tujuan syariah.
\end{abstract}

Kata Kunci :

Dampak Covid-19, Perkembangan, Prospek, Perbankan Syariah.

\begin{abstract}
Abstrak : The Covid-19 pandemic has spread to various countries, including Indonesia. The increasing number of Covid-19 cases is weakening the national and international economy. Various business sectors have experienced a slowdown due to the Covid-19 virus. In this research. It is hoped that sharia economic and business actors will show empathy and solidarity with stakeholders. Islamic business players take advantage of and support the government's stimulus program. Islamic banking and other financial institutions must start revising growth targets, applying digital transaction technology in one solution. Sharia economy and business can play a role in restoring economic shocks by prioritizing the achievement of sharia objectives.
\end{abstract}

Keywords : Impact of Covid-19, Development, Prospects, Islamic Banking.

\footnotetext{
$\triangle$ Corresponding Author:

E-mail address: miqbalfasa@radenintan.ac.id (Kec. Sukarame, Kota Bandar Lampung, Indonesia)

"Received 18 Februari 2021, Accepted 09 Maret 2021, Published 19 Juni 2021"
} 
Annisa Nur Safitri ${ }^{1}$, Muhammad Iqbal Fasa ${ }^{\bowtie 2}$, Suharto ${ }^{3}$

Dampak Pandemi Covid-19 terhadap Perkembangan dan Prospek Perbankan Syariah

DOI : https://doi.org/10.37531/ecotal.v2i2.66

\section{Pendahuluan}

Wuhan, sebuah kota di Republik Rakyat Tiongkok, mendadak terkenal di seantero dunia. Di kota berpenduduk sekitar 9 juta jiwa itu, serangan virus Corona (Covid-19) bermula. Tak hanya di daratan Tiongkok saja, virus ini juga telah menyebar ke lebih dari 180 negara/kawasan di dunia hingga Maret 2020. Organisasi Kesehatan Dunia (WHO) akhirnya mengumumkan status pandemi global pada 11 Maret 2020. Berdasarkan data yang ada, dampak Covid-19 pada ekonomi Tiongkok berakibat perlambatan pertumbuhan ekonomi dari 6,1\% tahun lalu menjadi hanya sekitar 3,8\% tahun ini, dengan catatan pandemi tidak bertambah buruk. Jika keadaan memburuk pertumbuhan bisa hanya 0,1\% atau bahkan minus (Iskandar, Possumah and Aqbar, 2020).

Perbankan Syariah adalah salah satu aspek yang kedepannya sangat menjanjikan untuk Indonesia, perkembangan perbankan saat ini juga dinilai sangat pesat. Kemajuan perkembangan perbankan syariah saat ini bukanlah tanpa halangan dan tantangan perkembangan yang sangat pesat itu juga penuh dengan risiko yang harus dihadapi. Perbankan syariah adalah suatu sistem yang dibangun dengan semangat alternatif, sehingga harus berbeda dari perbankan yang telah ada. Perbedaan sistem tidak sekedar pemakaian istilah, tetapi juga perlakuan terhadap jaminan rasa aman terhadap nasabah. Oleh karena itu, pencantuman label syariah, pada hakikatnya mengandung konsekuensi yang cukup berat, sehingga mekanisme pengawasannya perlu diperketat agar menjaga amanah dan kepercayaan nasabah terjaga dengan baik (Fauziah, Fakhriyah and Abdurrohman, 2020).

Di Indonesia kasus pertama Covid-19 diumumkan pada tanggal 2 Maret 2020 terkonfirmasi positif Covid-19 pada dua warga depok, Jawa Barat, yang berawal dari suatu acara di Jakarta dimana penderita kontak langsung dengan seorang warga negara asing (WNA) asal jepang yang tinggal di malaysia. Setelah pertemuan tersebut penderita mengeluhkan demam, batuk dan sesak napas.4 Serangan Covid-19 pada awal maret 2020 tentu sangat terasa dampaknya, menyikapi pandemi Covid-19 kebijakan mulai dimunculkan, mulai penerapan Work From Home (WFH) diantara bentuk upaya yang diserukan dan dilakukan oleh dunia untuk mengurangi penyebaran Covid-19 ini adalah dengan social atau Physical Distancing, sampai diberlakukan Pembatasan Sosial Bersekala Besar (PSBB) namun sayangnya, gerakan tersebut berpengaruh pada penurunan aktivitas ekonomi secara keseluruhan. Berikut data statistik perubahan mobilitas penduduk Indonesia setelah diberlakukan Work From Home (WFH)(Tahliani, 2020). 
Annisa Nur Safitri' ${ }^{1}$, Muhammad Iqbal Fasa ${ }^{\bowtie 2}$, Suharto $^{3}$

Dampak Pandemi Covid-19 terhadap Perkembangan dan Prospek Perbankan Syariah

DOI : https://doi.org/10.37531/ecotal.v2i2.66

(Azhari and Wahyudi, 2020) meneliti tentang Pandemi Covid-19 mempengaruhi kinerja perbankan syariah yang ditunjukkan dengan gejolak fluktuasi terutama diawal masa pandemi Covid-19. Kinerja pada bank syariah mengalami fluktuasi pada sisi DPK dan debt financing. Pada sisi pembiayaan sewa mengalami penurunan yang cukup konstan pada masa pandemi. Sedangkan pada sisi equity financing mengalami pertumbuhan yang cukup signifikan dan stabil. Hal ini semakin memperkuat teori bahwa sistem bagi hasil yang digunakan pada produk bank syariah; equity financing mampu bertahan terhadap kondisi gejolak ekonomi domestik dan internasional. (Sugiri, 2020) meneliti tetang dimana sektor UMKM di Indonesia mengalami dampak dari Pandemi COVID-19. Dampak tersebut berturut adalah penurunan penjualan, kesulitan permodalan, hambatan distribusi produk, serta kesulitan bahan baku. Pemerintah telah mengeluarkan kebijakan dalam rangka memperdayakan UMKM dalam situasi pandemi COVIDTerdapat beberapa skema perlindungan UMKM yang dilakukan pemerintah yaitu (a) pemberian bantuan sosial kepada pelaku UMKM miskin dan rentan, (b) insentif pajak bagi UMKM; (c) relaksasi dan restrukturisasi kredit bagi UMKM; (d) perluasan pembiayaan modal kerja UMKM; (d) menempatkan kementerian, BUMN dan pemerintah Daerah sebagai penyangga produk UMKM; dan (e) pelatihan secara e-learning.

Tujuan penelitian ini adalah untuk mengetahui dampak Covid-19 terhadap perkembangan dan prospek perbankan syariah. Penelitian ini penting untuk dilakukan karena perbankan syariah di Indonesia menganut sistem dual banking dan memiliki kerakteristik yang unik dimana bank syariah dianggap mampu bertahan dalam menghadapi berbagai macam krisis ekonomi.

\section{Metode Penelitian}

Jenis penelitian ini bersifat deskriptif kualitatif yang merupakan sebuah metode penelitian yang memanfaatkan data kualitatif dan dijabarkan secara deskriptif. Pengumpulan data metode ini adalah dengan menggunakan data sekunder yang berasal dari berbagai literatur seperti bukubuku, artikel, serta homepage untuk mengakses data dan informasi terkini. Penggunaan metode kualitatif deskriptif bertujuan untuk memberikan deskripsi serta mendapatkan gambaran yang jelas. Penelitian ini juga untuk menelaah sumber-sumber tertulis seperti jurnal ilmiah, buku referensi, literature, ensiklopedia, karangan ilmiah, karya ilmuah serta sumber-sumber lain baik dalam bentuk tulisan atau dalam format digital yang relevan dan berhubungan dengan objek kajian penelitian ini adalah berupa teks-teks atau tulisan-tulisan. 


\section{Hasil Penelitian dan Pembahasan}

\subsection{Perkembangan Perbankan Syariah:}

Perbankan syariah mulai diakui eksistensinya pada saat dikeluarkannya UU No.7 Tahun 1992 tentang bank yang menerapkan konsep bagi hasil, meskipun tidak disebutkan secara jelas terkait prinsip syariahnya. Semenjak itu Bank Muamalat yang merupakan bank Islam pertama mulai beroperasi di Indonesia. Eksistensi perbankan syariah semakin kuat ketika disahkannya UU No.10 Tahun 1998 sebagai amandemen dari UU No.7 Tahun 1992. Dalam undang-undang yang diperbaharui tersebut disebutkan secara jelas bahwa Bank Umum maupun Bank Perkreditan Rakyat yang beroperasi secara konvensional dan/atau berdasarkan prinsip syariah. Lalu kemudian pada tahun 2008, disahkannya UU No.21 Tahun 2008 oleh Presiden Susilo Bambang Yudhoyono tentang Perbankan Islam, dimana regulasi ini yang digunakan sampai saat ini. Dibalik perkembangan regulasi perbankan syariah, terekam sebuah fakta bahwa kemunculan perbankan dengan sistem syariah ini sebagai jawaban atas permintaan masyarakat Indonesia yang menginginkan bank bebas bunga. Akan tetapi setelah dilegalkan beroperasi di Indonesia pada tahun 1992, perbankan syariah tidak berkembang dengan pesat(Iryana, 2018).

Bank Muamalat Indonesia (BMI) mulai beroperasi. Pendirian Bank Muamalat ini diikuti oleh Bank Perkreditan Rakyat Syariah (BPRS). Namun demikian, keberadaan dua jenis lembaga keuangan tersebut belum sanggup menjangkau masyarakat Islam lapisan bawah. Oleh karena itu, dibentuklah lembaga-lembaga keuangan mikro syariah yang disebut Baitul Maal Wattamwil (BMT)(Nofinawati, 2015).

Ada beberapa prinsip konsep Islam. (1) transaksi harus berasaskan manfaat (faedah). Menurut Islam, pemilik harta hanya boleh mendapat hasil yang merupakan fungsi manfaat dari pemakaian harta tersebut, baik oleh dirinya sendiri maupun oleh pihak lain. (2) uang diperlukan sebagai sarana pertukaran, karena tidak boleh digunakan sebagai komoditi. Kepemilikan uang sematamata tidak boleh memberikan tambahan/keuntungan. (3) transaksi harus spesifik dan transparan, karena dalam syariah Islam, transaksi harus didasarkan pada itikad baik, sehingga tidak boleh terdapat gharar. (4) risiko transaksi harus dikelola dengan baik karena dalam Islam dilarang adanya maysir (risiko akibat mencari kekayaan yang mudah). Maysir yang terbesar adalah dalam situasi zero sum game, di mana keuntungan suatu pihak merupakan kerugian pihak

Volume 2 Issue 2 (2021)

Economics and Digital Business Review

ISSN: $\underline{\text { 2774-2563 }}$ (Online) 
Annisa Nur Safitri' ${ }^{1}$, Muhammad Iqbal Fasa ${ }^{\bowtie 2}$, Suharto $^{3}$

Dampak Pandemi Covid-19 terhadap Perkembangan dan Prospek Perbankan Syariah

DOI : https://doi.org/10.37531/ecotal.v2i2.66

lain. Tindakan ini umumnya disebut sebagai spekulan murni. (5) lembaga keuangan adalah pemegang amanah, karena dalam Islam, lembaga keuangan hanyalah pihak yang memberikan jasa pengelolaan keuangan sesuai dengan kesepakatan dengan pemilik dana(Shandy Utama, 2018). Bank syariah dipengaruhi oleh lima faktor intern maupun ekstern yang saling mendukung. Kelima faktor tersebut adalah pengurus dan pemilik, nasabah/masyarakat, kompetitor, regulator/ pengawas dan infrastruktur. Pengurus dan pemilik dituntut memiliki integritas dan kompetensi, kepatuhan terhadap prinsip syariah, dan kepatuhan terhadap prundential regulation (prinsip kehati-hatian). Nasabah/masyarakat yang memiliki integritas, kompetensi, dan loyalitas. Kompetitor/Subtitusi yang terdiri dari perbankan konvensional dan lembaga keuangan lainnya. Regulator, pengawas, dan badan lainnya yang terdiri BI; Perijinan, Pengaturan dan Pengawasan, DSN ; fatwa kegiatan usaha dari DPS, IAI, PSAK, PAPSI, Pedoman Audit, Badan Arbitrasi dan lainlain, dan Infrastruktur yang terdiri dari kondisi makro ekonomi ; sektor riil, moneter, fiskal dan luar negeri(Alanshori, 2016).

Di Indonesia prospek perbankan syariah makin cerah dan menjanjikan. Bank syariah di negeri ini, diyakini akan terus tumbuh dan berkembang di masa depan. Perbankan syariah dapat dikategorikan sebagai jenis industri baru yang mempunyai daya tarik cukup tinggi. Hal ini dapat dilihat dari banyaknya pemain baru yang bermain, tidak hanya dalam bentuk bank umum dan BPRS, tetapi juga dalam bentuk UUS(Nofinawati, 2015). Untuk lebih jelasnya, di bawah ini akan penulis paparkan sebagai berikut :

Tabel 1. Perkembangan kelembagaan dan kinerja perbankan syariah di Indonesia

\begin{tabular}{ccccccc}
\hline \multirow{2}{*}{ Indikator } & \multicolumn{7}{c}{ Periode } \\
\cline { 2 - 7 } & $\mathbf{2 0 1 4}$ & $\mathbf{2 0 1 5}$ & $\mathbf{2 0 1 6}$ & $\mathbf{2 0 1 7}$ & $\mathbf{2 0 1 8}$ & $\mathbf{2 0 1 9}$ \\
\hline BUS & 2.163 & 1.990 & 1.869 & 1.825 & 1.875 & 1.919 \\
\hline UUS & 320 & 311 & 332 & 344 & 354 & 381 \\
\hline BPRS & 439 & 439 & 453 & 441 & 495 & 617 \\
\hline Asset (Triliun Rp) & 279 & 304 & 366 & 435 & 490 & 538 \\
\hline DPK (Triliun Rp) & 222 & 236 & 285 & 342 & 380 & 425 \\
\hline PYD (Triliun Rp) & 204 & 219 & 255 & 293 & 329 & 365 \\
\hline Jaringan Kantor & 2.910 & 2.747 & 2.654 & 2.610 & 2.556 & 2.753 \\
\hline
\end{tabular}

Sumber : Data Statistik Perbankan Syariah OJK (http://www.ojk.go.id) data diolah 


\section{Keterangan :}

BUS : Bank Umum Syariah

UUS : Unit Usaha Syariah

BPRS : Bank Pembiayaan Rakyat Syariah

DPK : Dana Pihak Ketiga

Gambar 1. Diagram Grafik 1 Pertumbuhan BUS, UUS, BPRS

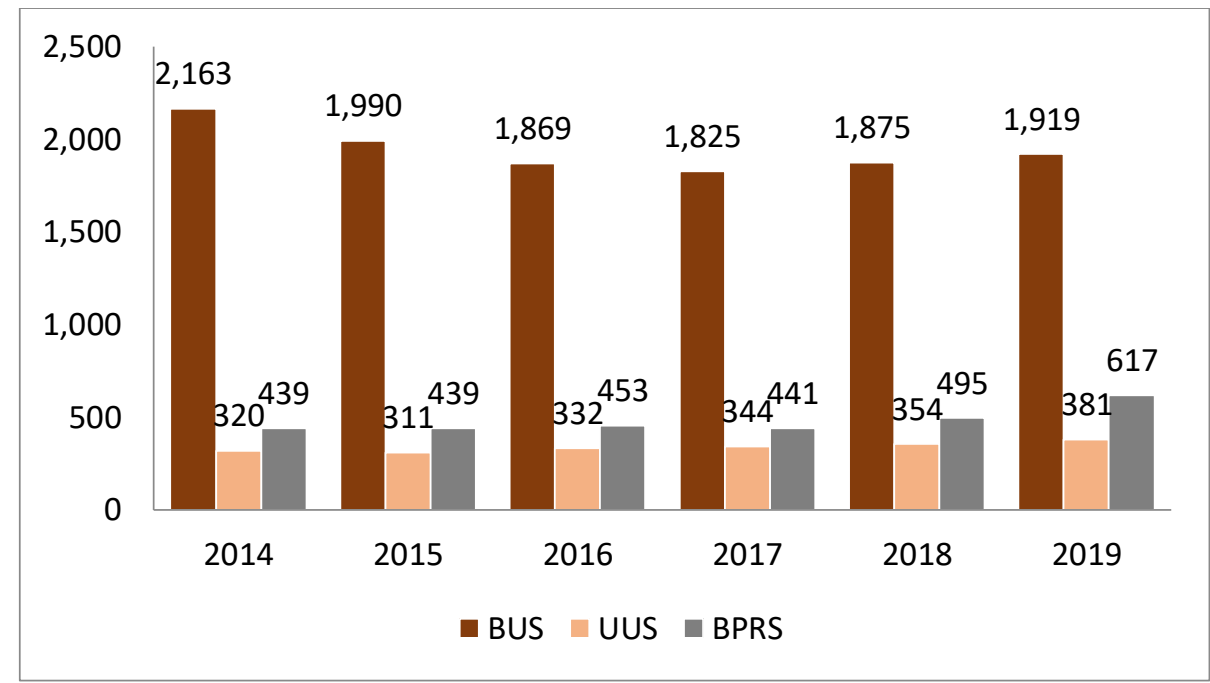

Berdasarkan diagram di atas, dapat dilihat bahwa pertumbuhan perbankan syariah dari segi lembaganya selalu mengalami peningkatan. Namun pada tahun 2014 s.d 2017 Bank Umum Syariah mengalami penurunan jumlah yang lumayan, walaupun peningkatannya perlahan, namun pertumbuhan yang paling pesat terjadi pada tahun 2017 s.d. 2019, seiring berkembangnya Bank Umum Syariah jika dilihat dari jumlah Unit Usaha Syariah di Indonesia dari tahun 2014 s.d. tahun 2019 perbankan syariah juga selalu mengalami peningkatan secara perlahan yang mengalami penaikan walaupun pada tahun 2014 sampai 2015 mengalami penurunan. Begitu juga dengan jumlah Bank Pembiayaan Rakyat Syariah selalu mengalami perningkatan dari tahun 2014 s.d. 2019. 
Annisa Nur Safitri' ${ }^{1}$ Muhammad Iqbal Fasa ${ }^{\bowtie 2}$, Suharto $^{3}$

Dampak Pandemi Covid-19 terhadap Perkembangan dan Prospek Perbankan Syariah

DOI : $\underline{\text { https://doi.org/10.37531/ecotal.v2i2.66 }}$

Gambar 2. Diagram Grafik 2 Pertumbuhan Jaringan Kantor

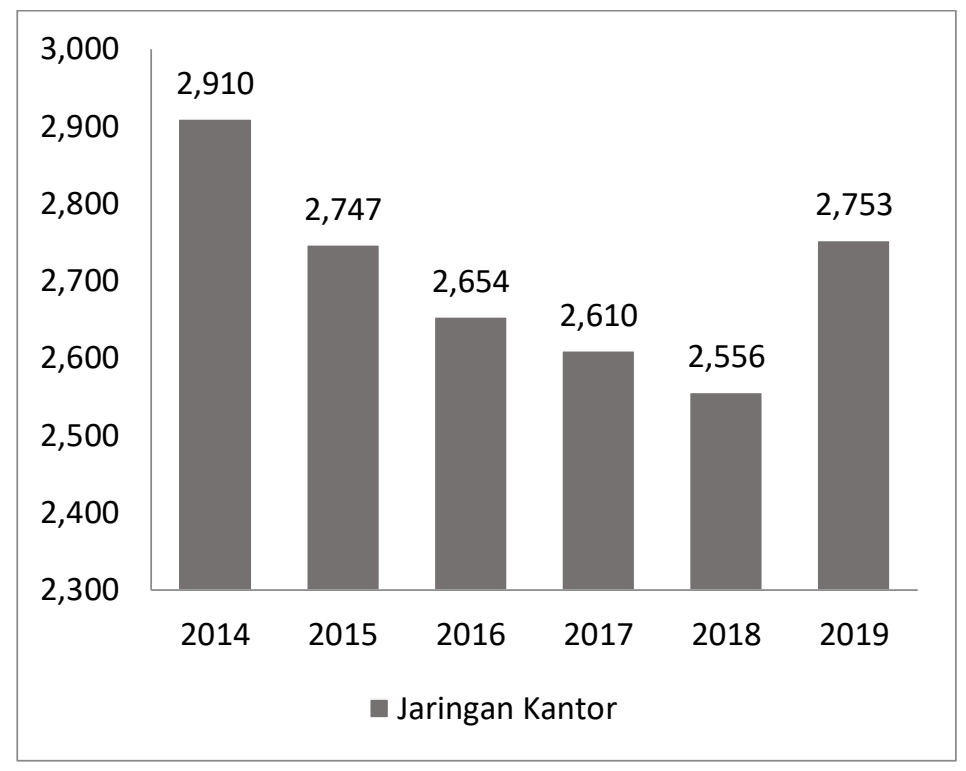

Dari jaringan kantor, perbankan syariah di Indonesia menunjukkan kinerja yang sangat bagus.

Hal itu terlihat pada data statistik perbankan syariah yang dipublikasikan oleh Otoritas Jasa Keuangan, di mana pertumbuhan pada tahun 2014 dari jaringan kantor diatas yaitu 2.910, pada tahun 2015 dari jaringan kantor diatas yaitu 2.747, pada tahun 2016 dari jaringan kantor diatas yaitu 2.654, pada tahun 2017 dari jaringan kantor diatas yaitu 2.610, pada tahun 2018 dari jaringan kantor diatas yaitu 2.556, pada tahun 2019 dari jaringan kantor diatas yaitu 2.753.

Gambar 3. Grafik Diagram 3 Perkembangan Asset, DPK, dan PYD

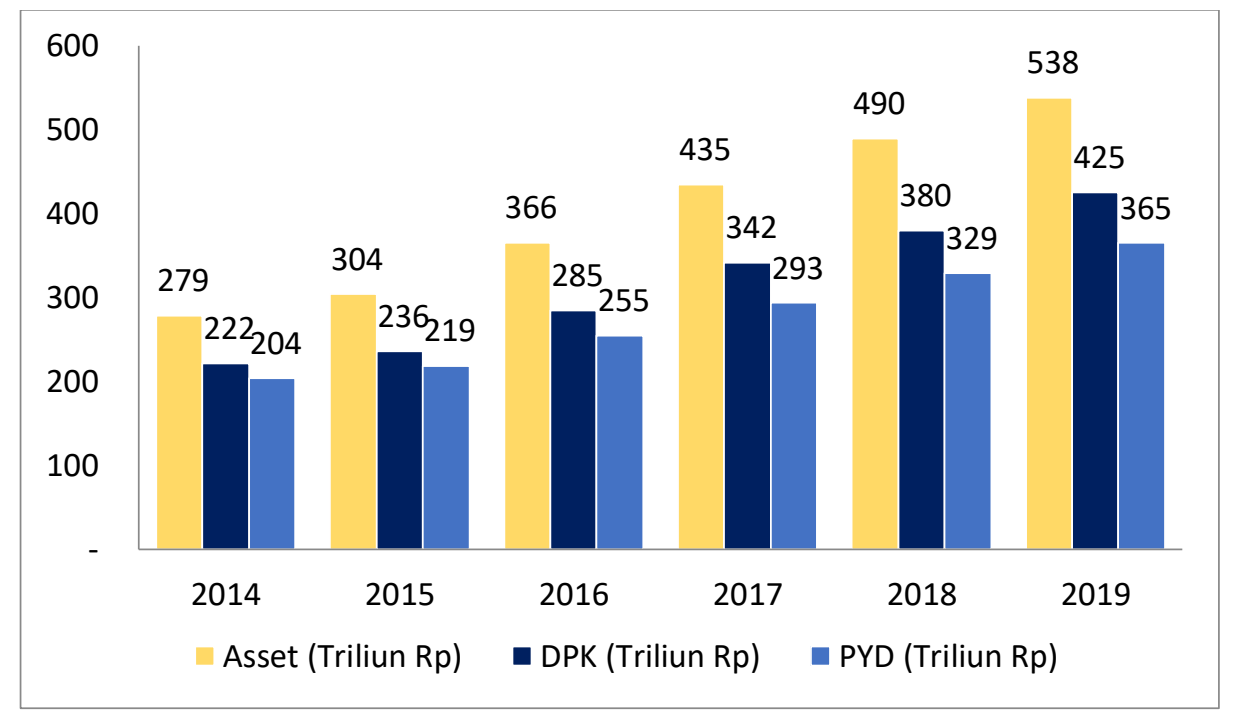


Annisa Nur Safitri ${ }^{1}$, Muhammad Iqbal Fasa ${ }^{\bowtie 2}$, Suharto ${ }^{3}$

Dari aspek penghimpunan dana dan penyaluran dana, perbankan syariah di Indonesia menunjukkan kinerja yang sangat bagus. Hal itu terlihat pada data statistik perbankan syariah yang dipublikasikan oleh Otoritas Jasa Keuangan, di mana pertumbuhan jumlah asset, jumlah DPK (Dana Pihak Ketiga), dan PYD (Pembiayaan Yang Disalurkan) selalu mengalami peningkatan dari tahun ke tahun(Suhendro, 2018).

\subsection{Pertumbuhan Asset}

Apabila ditinjau dari penghimpunan dan penyaluran dana, perbankan syariah di Indonesia selalu memperlihatkan kinerja yang terus meningkat. Dapat dilihat dari diagram diatas dan data-data statistik perbankan syariah yang di tampilkan pada Otoritas Jasa Keuangan (OJK). Pertumbuhan dan perkembangan jumlah aset selalu meningkat dari tahun 2014 sampai 2019. Aset Pada tahun 2014 aset mengalami peningkatan sebesar 279,91 atau 12,42\%, pada tahun 2015 mengalami pertumbuhan sebesar 304.00 atau 9,00\%, dari tahun sebelumnya. Pada tahun 2016 mengalami peningkatan 365,60 atau 20,28\%. Pada tahun 2017 aset mengalami peningkatan sebesar 435,01 atau 18,97\%. Pada tahun 2018 aset mengalami peningkatan sebesar 490,69 atau 12,57\%. Pada tahun 2019 aset mengalami peningkatan sebesar 538,32 atau 9,93\%. Pertumbuhan dan perkembangan Asset Perbankan Syariah dapat dilihat dari tahun 2014-2019 meningkat sangat pesat menjadikan perbankan syariah mencapai tingkat lebih tinggi walaupun perbankan konvensional masih memimpin.

\subsection{Pertumbuhan DPK}

Dapat dilihat dari diagram diatas bahwa DPK (Dana Pihak Ketiga) pada tahun 2014-2019 mengalami peningkatan yang sangat pesat dari tahun ke tahunnya. Pada tahun 2014 DPK mengalami peningkatan menjadi 222,89 atau 18,53\%. Pada tahun 2015 mengalami pertumbuhan sebesar 236,02 atau 6,37\% dari tahun sebelumnya. Pada tahun 2016 DPK mengalami peningkatan menjadi 285,20 atau 20,84\%. Pada tahun 2017 DPK mengalami peningkatan menjadi 341,71 atau 19,89\%. Pada tahun 2018 DPK mengalami peningkatan menjadi 379,96 atau 11,14\%. Pada tahun 2019 DPK mengalami peningkatan menjadi 365,13 atau 11,94\%.

\subsection{Pertumbuhan PYD}

Dapat dilihat dari diagram diatas bahwa PYD (Pembiayaan yang Disalurkan) pada tahun 20142019 mengalami peningkatan yang sangat pesat dari tahun ke tahunnya Sementara untuk PYD (Pembiayaan yang Disalurkan) Pada tahun 2014 PYD mengalami peningkatan menjadi 204,33 atau 8,37\%, pada tahun 2015 mengalami pertumbuhan sebesar 218,72 atau 7,06\% dari tahun sebelumnya. Pada tahun 2016 PYD mengalami peningkatan sebesar 254,70 atau $16,41 \%$. Pada tahun 2017 PYD mengalami peningkatan menjadi 293,46 atau 15,24\%. Pada tahun 2018 PYD mengalami peningkatan menjadi 329,28 atau 12,21\%. Pada tahun 2019 PYD mengalami peningkatan menjadi 365,13 atau $10,89 \%$. 
Annisa Nur Safitri' ${ }^{1}$, Muhammad Iqbal Fasa ${ }^{\bowtie 2}$, Suharto $^{3}$

Dampak Pandemi Covid-19 terhadap Perkembangan dan Prospek Perbankan Syariah

DOI : $\underline{\text { https://doi.org/10.37531/ecotal.v2i2.66 }}$

\section{Prospek Perbankan Syariah}

Eksistensi perbankan sebagai layanan jasa keuangan berbasis pada kepercayaan nasabah. Sebagaimana diatur dalam ketentuan perbankan dalam Undang - Undang No. 7 Tahun 1992, tentang Perbankan Jo Undang - undang No. 10 Tahun 1998 tentang perubahan UU Perbankan dengan adanya ketentuan syariah, yang dimaksud dengan Perbankan adalah segala sesuatu yang menyangkut tentang bank, mencakup kelembagaan, kegiatan usaha, serta cara dan proses dalam melaksanakan kegiatan usahanya. Dengan adanya UU No. 10 Tahun 1998 maka berlaku dual system dalam pengelolaan bank, yakni secara konversional dengan menggunakan bunga (interrest) untuk setiap peminjaman atau penyimpangan dana, serta menggunakan sistem bagi hasil yang merupakan dasar perbankan syariah(Zumaroh, 2018).

Faktor utama sebagai dasar pertimbangan bagi nasabah dalam memilih layanan perbankan adalah kepercayaan atas kinerja profersional perbankan, seperti jaminan keamanan dana nasabah, efektifitas dan efisien layanan jasa perbankan. Faktor bunga tidaklah menjadi alasan utama nasabah dalam memilih jasa perbankan, sebagian masyarakat tidak terlalu memperhatikan masalah atas bunga tersebut dan lebih mengutamakan efektifitas, efisiensi dan keamanan atas dana yang disimpan oleh lembaga perbankan. Tetapi kepercayaan masyarakat yang sempat goyah terhadap perbankan konvensional akibat krisis moneter dan perbankan tahun 1997 tersebut, kembali pulih dan tetap menjadi mainstream bagi masyarakat dengan alasan kepercayaan atas profesional perbankan (Sholikhin, 2013).

Menanggapi timbulnya interrest masyarakat atas prinsip syariah, perbankan konvensional pun dengan responsif mengembangkan layanan dengan membuka unit syariah dalam fasilitas layanan jasa perbankan. Dengan profesional kinerja perbankan dan kredibilitas yang sudah disandangnya, keberadaan unit perbankan syariah dalam perbankan konvensional telah menjadi kompetitor bagi perbankan syariah. Munculnya fatwa MUI bahwa bunga bank adalah riba, patut dihargai sebagai upaya sosialisasi aktivitas perbankan berdasarkan perspektif keislaman. Namun, keputusan untuk memilih penggunaan layanan jasa perbankan konversional atau syariah tetap berada pada pihak nasabah. Dan hal yang wajar apabila sebagian besar nasabah akan memilih layanan jasa perbankan atas dasar porfesionalisme. Jadi bagi lembaga perbankan syariah, fatwa MUI akan mempertegas kehadiran perbankan syariah bagi masyarakat Indonesia yang mayoritas warga negaranya beragam Islam(Pikir, 2014).

Paradigma kebijakan yang diperlukan untuk menjamin konsistensi peran dalam pengembangan perbankan syariah antara lain : pengembangan SDM perbankan syariah, pengembangan instrumen - instrumen layanan jasa perbankan syariah, sosialisasi program dan layanan jasa perbankan syariah, profesionalisme kinerja dan layanan jasa perbankan, segmentasi pasar perbankan syariah, dan Pengembangan networking dalam skala nasional maupun internasional (Alamsyah, 2015). Realisasi kebijakan pengembangan syariah memang tidak bisa dilakukan dalam waktu singkat. Keberadaan fatwa MUI meneguhkan eksistensi perbankan syariah sebagai alternatif lembaga keuangan selain perbankan konvensional. Namun untuk bisa berkompetisi harus berorientasi pada profesionalisme dengan secara konsisten merealisasikan paradigma kebijakan perbankan syariah yang tertulis di atas. 
Annisa Nur Safitri ${ }^{1}$, Muhammad Iqbal Fasa ${ }^{\bowtie 2}$, Suharto ${ }^{3}$

Dampak Pandemi Covid-19 terhadap Perkembangan dan Prospek Perbankan Syariah

DOI : https://doi.org/10.37531/ecotal.v2i2.66

\section{Dampak Pandemi Covid-19}

Pandemi covid-19 ini berdampak pada penurunan pertumbuhan ekonomi secara global. Hal tersebut merupakan pukulan hebat terutama di bidang pariwisata, UMKM, perhotelan dan banyak bidang lainnya yang mengakibatkan banyaknya karyawan mengalami putus hubungan kerja dan naiknya kelompok orang miskin. Secara sosial hal ini berdampak pada terganggunya akses pangan, penurunan kesehatan dan kesejahteraan masyarakat akan tetapi sebaliknya berdampak baik bagi lingkungan. Berkurangnya aktivitas masyarakat di luar rumah, baik karena lockdown maupun Pembatasan Sosial Berskala Besar (PSBB) ternyata membuat dampak yang baik bagi lingkungan. Kualitas udara dan air mengalami perbaikan, keragaman hayati meningkat dan berkurangnya perdagangan satwa liar, akan tetapi terjadi kenaikan pada sampah plastik dan non plastik akibat meningkatnya alat pengaman diri(Kuncara and Dkk, 2020).

Selama berlangsungnya covid-19 masyarakat melakukan kegiatannya melalui aneka ragam digital yang tersedia, baik untuk kegiatan pekerjaan, spiritual maupun kebutuhan rumah tangga. Mulai dari aplikasi pertemuan hingga pemesanan makanan booming dipakai oleh banyak individu saat ini, begitupun untuk transaksi dalam bidang perbankan, di mana bukan hanya kegiatan komersial namun juga ikut serta mengurangi dampak pandemik(Komalasari, 2020).

\section{Dampak Pandemi Covid-19 terhadap Perkembangan Perbankan Syariah}

Menurut J.P Morgan Ada tiga risiko yang membayangi industri perbankan dalam masa pandemi covid-19 yaitu penyaluran kredit, penurunan kualitas aset dan pengetatan margin bunga bersih. Dari ketiga risiko tersebut mari kita analisa apakah bank syariah lebih kuat dalam menghadapi krisis ekonomi akibat pandemi covid-19 dibandingkan bank konvensional atau malah sebaliknya(Sunaria and Itsnaini, 2020).

1. Penyaluran kredit (pembiayaan) Dalam hal ini bank syariah maupun bank konvensional akan mengalami kondisi yang sama. Baik bank syariah maupun bank konvensional akan sama- sama mengalami pelambatan penyaluran kredit (pembiayaan).

2. Penurunan kualitas aset Dalam hal ini baik bank syariah maupun bank konvensional akan sedikit terbantu dengan adanya POJK No.11/POJK.03/2020. POJK tersebut akan membantu bank syariah maupun bank konvensional terutama dalam Pengetatan margin bunga bersih Hal tersebut dikarenaka bank syariah menggunakan sistim bagi hasil seperti yang disampaikan dalam penjelasan di atas. Dengan sistim bagi hasil maka kondisi neraca bank syariah pada mas krisis akibat pandemi covid-19 ini akan elastis karena besarnya biaya yang diperuntukkan buat pembayaran bagi hasil juga akan ikut menurun dengan penurunan pendapatan yang diperoleh bank syariah. Hal ini berbeda dengan bank konvensional yang mana disaat pendapatan bunga kredit menurun tidak diikuti dengan penurunan biaya bunga untuk deposan, inilah yang akan menjadi permaslahan serius dari bank konvensional. pencadangan penyisihan penghapusan aktiva produktif. Bank syariah diprediksi akan memiliki keunggulan dibandingkan dengan bank konvensional.

3. Pengetatan margin bunga bersih Hal tersebut dikarenaka bank syariah menggunakan sistim bagi hasil. Dengan sistim bagi hasil maka kondisi neraca bank syariah pada mas 
Annisa Nur Safitri ${ }^{1}$, Muhammad Iqbal Fasa ${ }^{\bowtie 2}$, Suharto ${ }^{3}$

krisis akibat pandemi covid-19 ini akan elastis karena besarnya biaya yang diperuntukkan buat pembayaran bagi hasil juga akan ikut menurun dengan penurunan pendapatan yang diperoleh bank syariah. Hal ini berbeda dengan bank konvensional yang mana disaat pendapatan bunga kredit menurun tidak diikuti dengan penurunan biaya bunga untuk deposan, inilah yang akan menjadi permaslahan serius dari bank konvensional.

Dengan adanya factor-faktor tersebut yaitu saat perbankan nasional diprediksi akan mengalami depresi akibat pandemi covid-19. dalam bank syariah ada beberapa hal keunggulan terhadap bank konvensional sehingga bisa menjadi solusi yang terhadap pandemi covid-19, yakni : Di saat perbankan nasional diprediksi akan mengalami depresi akibat pandemi covid-19, bank syariah memiliki kelebihan dengan konsep bagi hasilnya untuk bisa satu level lebih kokoh dalam menghadapi krisis. Keunggulan disaat masa-masa sulit ini tentunya menjadi peluang yang bagus untuk penguatan market share bank syariah(Ningsih and Mahfudz, 2020).

Melihat tiga risiko yang akan dihadapi oleh perbankan seperti disampaikan oleh JP Morgan di atas maka bank syariah harus jeli untuk menentukan strategi di tengah pandemi covid-19. Melakukan ekspansi yang terukur ke segmen digital adalah opsi yang cukup menantang yang bisa diambil oleh bank syariah.

\section{Prospek Perbankan Syariah terhadap Dampak Pandemi Covid-19}

Adapun Prospek dan Tantangan Perbankan Syariah adalah sebagai berikut (Fasa, 2013) :

1. Mendorong inovasi produk perbankan syariah yang kreatif dan efisien.

2. Penyiapan SDM dalam kuantitas dan kualitas yang memadai.

3. Perbaikan kualitas layanan prima bagi nasabah agar kompetitif dengan perbankan lainnya.

4. Pemanfaatan IT secara optimal untuk mendorong pencipta- an produk-produk unggulan.

5. Pelayanan pembiayaan sektor UMKM dan sektor produktif lainnya guna mendorong pertumbuhan ekonomi dan penciptaan lapangan kerja.

6. Sosialisasi, edukasi dan diseminasi gagasan ekonomi kepada masyarakat secara lebih intensif dan massif.

7. Peningkatan jumlah penyertaan modal sendiri untuk me- menuhi ketentuan aturan dari Bank Indonesia.

Pemerintah Indonesia mulai concern dengan kebijakan-kebijakan mengenai perbankan syariah, ditandai dengan (Kuncara and Dkk, 2020) :

1. Pemerintah dan DPR sepakat untuk membuat sebuah badan pengelola keuangan haji dan industri perbankan syariah sebagai bagian dari pengelolaan dana haji berdasarkan Undang-undang Nomor 34 Tahun 2014 tentang Pengelolaan Dana Haji.

2. Pemerintah mendorong untuk tumbuhnya industri syariah nasional di mana salah satunya adalah memberikan kebijakan-kebijakan untuk industri perbankan syariah melalui komite, hal tersebut berlandaskan Peraturan Presiden Republik Indonesia No.91 Tahun 2016 Tentang Komite Nasional Keuangan Syariah. 
Annisa Nur Safitri ${ }^{1}$, Muhammad Iqbal Fasa ${ }^{\bowtie 2}$, Suharto ${ }^{3}$

3. Bank umum konvensional dan bank umum syariah dapat menjadi bank penyalur dana gaji pegawai negeri berdasarkan Peraturan Menteri Keuangan No. 11/PMK.05/2016 yang Mengatur Tentang Penyaluran Gaji Melalui Rekening PNS Pusat, Prajurit TNI dan Anggota Polri melalui Bank Umum yang Dilakukan secara Terpusat.

4. Bank syariah menjadi bagian dari bank yang ditunjuk sebagai pengelola dana rekening khusus (reksus) yang dikelola oleh pemerintah pusat (kementrian keuangan) untuk program-program pemerintah berdasarkan Peraturan Menteri Keuangan No. 182 / PMK.05/2017 tentang Pengelolaan Rekening Milik Satuan Kerja Ruang Lingkup Kementrian Negara/Lembaga.

5. Pemerintah mewajibkan setoran biaya penyelenggaraan ibadah haji wajib dilakukan di Bank Syariah maupun Bank Konvensional yang memiliki Unit Usaha Syariah berlandaskan Peraturan Menteri Agama No. 30 Tahun 2013 tentang Bank Penerima Setoran Biaya Penyelenggaraan Ibadah Haji.

\section{Strategi Perbankan Syariah Terdahadap Dampak Pandemi Covid-19}

Adapun strategi bank syariah yang dapat dilakukan di tengah pandemic (Nurul Fitri Habibah, 2020), yaitu melalui Pertama, bank harus mengelola mitigasi risiko dengan tepat. Bank harus punya peta navigasi baru untuk dapat menghadapi krisis yang ada. Proses mapping debitur untuk proses restrukrisasi harus segera jalan dan jelas sehingga cashflow bank terlihat setelah melakukan treatment. Kedua, bank harus fokus pada industri yang prospek untuk dibiayai. Bank harus tebang pilih pada sektor usaha yang eksis dan berkembang di tengah merebaknya wabah Korona. Harapannya, bank tidak lagi bekerja dengan membawa beban kredit macet atas ekspansi kredit barunya. Ketiga, digital banking. Layanan produk dan jasa harus dikonversi menjadi digital banking. Proses tersebut harus berjalan bertahap dan inisiasinya dilakukan secara terus menerus. Keempat, inovasi dan kreativitas bank. Korona menuntut bank harus semakin berinovasi. Misalkan, bank saat ini tidak hanya menuntut pembayaran angsuran dan bunga kredit oleh debiturnya. Namun, bank juga harus memikirkan untuk dapat membantu nasabah, melalui penjualan produknya. Kelima, pendampingan dan konsultasi bisnis. Nasabah UMKM yang bisnisnya terganggu akibat Covid-19 mendapatkan pendampingan dan konsultasi bisnis oleh staf bank, yaitu relationship manager (RM) yang tersebar di seluruh Indonesia. Peran RM ini, akan melakukan pendampingan sekaligus sebagai konsultan apabila pinjaman nasabah dilakukan restrukturisasi hingga proses restrukturisasi tersebut berjalan lancar. Keenam, program Tanggung Jawab Sosial Perusahaan atau Corporate Social Responbility (CSR) melalui pendidikan dan pelatihan online bagi pelaku UMKM.

Kebijakan untuk meminimalkan dampak Covid-19, termasuk di sektor industri perbankan. Pemerintah melalui Otoritas Jasa Keuangan mengeluarkan Kebijakan Stimulus Perekonomian Nasional Sebagai Kebijakan Countercylical Dampak Penyebaran Coronavirus Disease 2019, penerbitan POJK No.11/POJK.03/2020. Kebijakan stimulus yang dimaksud terdiri atas kebijakan penilaian kualitas pembiayaan hanya didasarkan pada ketepatan pembayaran pokok dan margin/ bagi hasil/ujrah dengan pembiayaan mencapai 10 Miliar dan Skema Restrukturisasi pembiayaan. POJK No. 18/POJK.03/2020 mengambil langkah-langkah untuk menjaga stabilitas sistem 
Annisa Nur Safitri ${ }^{1}$, Muhammad Iqbal Fasa ${ }^{\bowtie 2}$, Suharto ${ }^{3}$

keuangan, terutama di sektor perbankan, ancaman pelemahan ekonomi akibat pandemi Covid19. OJK memberikan perintah kepada Bank untuk yang Pertama, melakukan merger, konsolidasi, pengambilalihan, dan atau integrasi. Kedua, menerima merger, konsolidasi, akuisisi, atau integrasi(Otoritas Jasa Keuangan, 2020)

Kebijakan tentang industri perbankan yang dikeluarkan oleh otoritas selama PSBB (SP 26/DHMS/ OJK/IV/2020). Menurut Siaran Pers dalam Operasi Industri Jasa Keuangan Selama Periode Implementasi PSBB di Berbagai Daerah. Isinya bahwa OJK meminta lembaga jasa keuangan untuk bekerja dengan jumlah minimum karyawan sesuai dengan protokol kesehatan di tempat kerja Lembaga layanan keuangan harus mematuhi prosedur PSBB untuk diimplementasikan, seperti physical distancing, mengurangi layanan dengan tatap muka dan sebagai gantinya perbankan dapat memaksimalkan penggunaan teknologi dan selalu menjaga kesehatan, sedangkan untuk peraturan pekerjaan dari rumah, diserahkan kepada masing-masing Lembaga Jasa Keuangan, sedangkan untuk pelaksanaan teknis pemberian akses dengan menunjukkan identitas karyawan dan Surat Tugas(Sumadi, 2020)

\section{Kesimpulan}

Perbankan syariah harus bisa menghadapi dampak dari Covid-19 terhadap perkembangan dan prospek perbankan syariah ini dalam dampaknya bagi perkembangan perbankan syariah yakni : (1) Penyaluran kredit (pembiayaan), (2) Penurunan kualitas asset, (3) Pengetatan margin bunga bersih. Dalam prospek dan strategi perbankan syariah yakni : Mendorong inovasi produk perbankan syariah yang kreatif dan efisien, Penyiapan SDM dalam kuantitas dan kualitas yang memadai, Perbaikan kualitas layanan prima bagi nasabah agar kompetitif dengan perbankan lainnya, Pemanfaatan IT secara optimal untuk mendorong penciptaan produk-produk unggulan, Pelayanan pembiayaan sektor UMKM dan sektor produktif lainnya guna mendorong pertumbuhan ekonomi dan penciptaan lapangan kerja, Sosialisasi, edukasi dan diseminasi gagasan ekonomi kepada masyarakat secara lebih intensif dan massif, dan Peningkatan jumlah penyertaan modal sendiri untuk me- menuhi ketentuan aturan dari Bank Indonesia. Dalam strategi perbankannya yakni : Pertama, bank harus mengelola mitigasi risiko dengan tepat. Kedua, bank harus fokus pada industri yang prospek untuk dibiayai. Ketiga, digital banking. Layanan produk dan jasa harus dikonversi menjadi digital banking. Keempat, inovasi dan kreativitas bank. Kelima, pendampingan dan konsultasi bisnis.. Keenam, program Tanggung Jawab Sosial Perusahaan atau Corporate Social Responbility (CSR) melalui pendidikan dan pelatihan online bagi pelaku UMKM. 
Annisa Nur Safitri ${ }^{1}$, Muhammad Iqbal Fasa ${ }^{\bowtie 2}$, Suharto ${ }^{3}$

\section{Referensi :}

Alamsyah, H. (2015) ‘Perkembangan dan Prospek Perbankan Syariah Indonesia’, pp. 1-8.

Alanshori, M. Z. (2016) 'PERKEMBANGAN, TANTANGAN, DAN PELUANG BANK SYARIAH', JES (Jurnal Ekonomi Syariah), 1(1), pp. 127-139.

Azhari, A. R. and Wahyudi, R. (2020) 'Analisis Kinerja Perbankan Syariah di Indonesia : Studi Masa Pandemi Covid-19', Jurnal Ekonomi Syariah Indonesia, 10(2), pp. 22-38. doi: 10.21927/jesi.v10i2.1462.

Fasa, M. I. (2013) 'Tantangan Dan Strategi Perkembangan Perbankan Syariah Di Indonesia', Jurnal EKONOMI ISLAM, 2(1), pp. 19-40.

Fauziah, H. N., Fakhriyah, A. N. and Abdurrohman (2020) 'Analisis Risiko Operasional Bank Syariah Pada Masa Pandemi Covid-19', Jurnal Ekonomi dan Perbankan Syariah, 6(2), pp. 38-45.

Iryana (2018) 'Perkembangan Perbankan Syariah Di Indonesia Dan Keberadaannya Sebagai Solusi', p. 121.

Iskandar, A., Possumah, B. T. and Aqbar, K. (2020) 'Peran Ekonomi dan Keuangan Sosial Islam saat Pandemi Covid-19', SALAM: Jurnal Sosial dan Budaya Syar-i, 7(7), pp. 625-638. doi: 10.15408/sjsbs.v7i7.15544.

Komalasari, R. (2020) 'Manfaat Teknologi Informasi Dan Komunikasi Di Masa Pandemi Covid 19', Jurnal Teknologi Informasi dan Komunikasi (TEMATIK), 7(1), pp. 38-50. doi: 10.38204/tematik.v7i1.369.

Kuncara, T. and Dkk (2020) Prediksi Ekonomi Indonesia Pasca Covid-19. Available at: https://books.google.co.id/books?id=KE8CEAAAQBAJ\&pg=PT162\&dq=Work+From+H ome+Covid+Indonesia\&hl=id\&sa=X\&ved=2ahUKEwiPi4GflenuAhXWfX0KHeGBCsgQ6A EwAnoECAIQAg\#v=onepage\&q=Work From Home Covid Indonesia\&f=false.

Ningsih, M. R. and Mahfudz, M. S. (2020) 'Dampak Pandemi Covid-19 Terhadap Manajemen Industri Perbankan Syariah: Analisis Komparatif', Jurnal Ekonomi dan Manajemen, 2(1), pp. 1-10. doi: 10.46918/point.v2i1.576.

Nofinawati (2015) Perkembangan Perbankan Syariah Di Indonesia, JURIS. doi: 10.31933/unesrev.v2i3.121.

Nurul Fitri Habibah (2020) 'Tantangan dan Strategi Perbankan Syariah dalam Menghadapi Covid19', Jurnal Ekonomi dan Perbankan Syariah (IQTISHODIAH), 2(1), pp. 1-9. Available at: https://ejournal.ibntegal.ac.id/index.php/iqtishodiah ISSN 2714-8572.

Otoritas Jasa Keuangan (2020) ‘OJK KELUARKAN PERATURAN TERKAIT PENANGANAN DAMPAK COVID-19'.

Pikir, T. W. (2014) ‘Prospek perbankan syariah pada masa mendatang', pp. 1-7. 
Shandy Utama, A. (2018) 'Sejarah dan Perkembangan Regulasi Mengenai Perbankan Syariah Dalam Sistem Hukum Nasional Di Indonesia', Jurnal Wawasan Yuridika, 2(2), pp. 187200. doi: 10.25072/jwy.v2i2.180.

Sholikhin, M. (2013) 'Prospek Perbankan Islam Dan Bisnis Syariâah Dalam Pengembangan Ekonomi', Iqtishadia: Jurnal Kajian Ekonomi dan Bisnis Islam STAIN Kudus, 6(2), pp. 241-258.

Sugiri, D. (2020) 'Menyelamatkan Usaha Mikro, Kecil dan Menengah dari Dampak Pandemi Covid19', Fokus Bisnis : Media Pengkajian Manajemen dan Akuntansi, 19(1), pp. 76-86. doi: 10.32639/fokusbisnis.v19i1.575.

Suhendro, D. (2018) 'Tinjauan Perkembangan dan Pertumbuhan Perbankan Syariah di Indonesia', Jurnal Ekonomi dan Bisnis Islam, 5(2), pp. 211-227.

Sumadi, S. (2020) 'Menakar Dampak Fenomena Pandemi Covid-19 Terhadap Perbankan Syariah', Jurnal Hukum Ekonomi Syariah, 3(2), pp. 145-162. doi: 10.30595/jhes.v0i1.8761.

Sunaria, M. J. S. and Itsnaini, P. R. (2020) ‘Dampak Covid-19 terhadap Lembaga Keuangan Syariah (PERBANKAN SYARIAH)’, pp. 1-17.

Tahliani, H. (2020) 'Tantangan Perbankan Syariah dalam Menghadapi Pandemi Covid-19', Madani Syari'ah, 3(2), pp. 92-113. Available at: https://stai-binamadani.ejournal.id/Madanisyariah/article/view/205.

Zumaroh (2018) 'Prospek Pengelolaan Keuangan Bank Syariah di Indonesia', FINANSIA: Jurnal Akuntansi dan Perbankan Syariah, 01(02), pp. 199-224. Available at: http://ejournal.metrouniv.ac.id/index.php/FINANSIA/article/download/1337/1164. 